\title{
SPECIATION OF Fe IN \\ AMBIENT AEROSOL AND CLOUDWATER
}

\author{
Thesis by \\ Ronald Lyn Siefert
}

Thesis Advisor

Michael R. Hoffmann

In Partial Fulfillment of the Requirements

for the Degree of

Doctor of Philosophy

California Institute of Technology

Pasadena, CA

1997

(Submitted August 15, 1996)

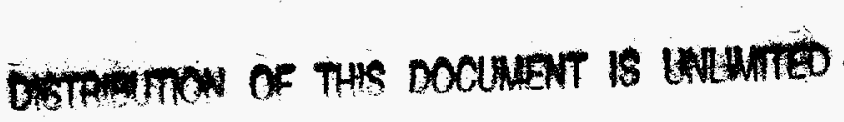

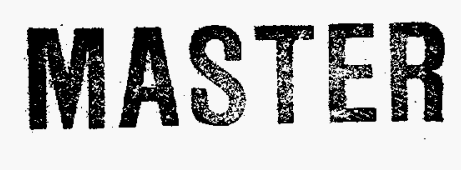




\section{DISCLAIMER}

This report was prepared as an account of work sponsored by an agency of the United States Government. Neither the United States Government nor any agency thereof, nor any of their employees, makes any warranty, express or implied, or assumes any legal liability or responsibility for the accuracy, completeness, or usefulness of any information, apparatus, product, or process disclosed, or represents that its use would not infringe privately owned rights. Reference herein to any specific commercial product, process, or service by trade name, trademark, manufacturer, or otherwise does not necessarily constitute or imply its endorsement, recommendation, or favoring by the United States Government or any agency thereof. The views and opinions of authors expressed herein do not necessarily state or reflect those of the United States Government or,any agency thereof. 


\section{DISCLAIMER}

Portions of this document may be illegible electronic image products. Images are produced from the best available original document. 
The Goverment reserves for itself and others acting on its behalf a royalty free, nonexclusive, irrevocable, world-wide license for govermental purposes to publish, distribute, translate, duplicate, exhibit, and perform any such data copyrighted by the contractor. 


\section{Acknowledgments}

This thesis (as most) is actually a collective work, with contributions from many people both directly and indirectly. I first want to thank my family for all of their support and love. My wife, Julie, has been a wonderful part of my life, ever since I first played soccer against her over 15 years ago at Chester Park in Duluth. I especially want to thank her for her patience and understanding during all of the field studies which have taken me to the other side of the world. It is always difficult to explain to people that these field studies to mountains, tropical islands and exotic ports is work, but she always understood. I also want to thank her for giving me two beautiful children, Jacob and Tara, who have enlightened our lives more then we probably know. It is always a great feeling to come home after a long day in the lab (or a long month at sea), and have your children give you a big hug and smile. I also want to thank my parents and sister who were also always there for me and supportive in all my decisions.

My advisor, Prof. Mike Hoffmann, gave me the independence to pursue my own ideas, and was always available to discuss science when I needed guidance. I also want to thank Prof. Morgan, whose door was always open when I had a question, and all of the faculty that I have had the opportunity to meet at Caltech. Their enthusiasm for discovery was very contagious.

I also want to thank all of the friends I have made at Caltech. My fellow students were always willing to either help me with a problem, or escape from it for a little while (or a long while). Mike Hannigan, Clo Butcher, Matt Fraser, Anne Johansen, Sam Webb, Jeremy Semrau, Simo Pehkonen, Peter Green, Janet Kesselman, Nicole Peill, Russ Mau, etc., truly made life at Caltech an enjoyable experience. I'll never forget the crossword breaks, mountain biking, softball games (followed by Super A's), barbecues, camping and countless other activities which filled in all that extra time I had. Playing and helping coach hockey with Bob Lane, Pavel Svitek, Dale Laird, etc., was certainly a great escape for me 
at Caltech. I highly recommend stapling a few people (especially from USC or UCLA) to the boards every now and then to relieve some of that graduate school stress. Of course I shouldn't forget to thank my orthopedic surgeons, physical therapists, USC Medical Center, Huntington Memorial Hospital, the paramedics/ambulance crew in Newport Beach, and of course my health insurance for making it all possible ( 15 years of injury free hockey in the land of 10,000 frozen lakes, and I get hurt my rookie season in L.A., how humiliating). I also would have been lost without the help of: Joe Fontana and Rich Eastvedt for actually constructing my sampling equipment; Rayma Harrison and Susan Leising for showing me the way through the maze of literature; and Linda Scott, Fran Matzen, Carmen Lopez and Jennifer Packman for knowing how to actually get things done. 


\section{ABSTRACT}

Atmospheric iron (Fe) is thought to play an important role in cloudwater chemistry (e.g., S(IV) oxidation, oxidant production, etc.), and is also an important source of Fe to certain regions of the worlds oceans where $\mathrm{Fe}$ is believed to be a rate-limiting nutrient for primary productivity. This thesis focuses on understanding the chemistry, speciation and abundance of $\mathrm{Fe}$ in cloudwater and aerosol in the troposphere, through observations of $\mathrm{Fe}$ speciation in the cloudwater and aerosol samples collected over the continental United States and the Arabian Sea. Different chemical species of atmospheric Fe were measured in aerosol and cloudwater samples to help assess the role of Fe in cloudwater chemistry. Chapter 2 presents a set of experiments which used ambient aerosol samples suspended in aqueous solution and then irradiated with uv-light to simulate cloudwater conditions. These experiments found $\mathrm{Fe}$ to be a critical component for the production of $\mathrm{H}_{2} \mathrm{O}_{2}$. Chapter 3 discusses the development and application of a novel photochemical extraction method for the determination of photochemically-available $\mathrm{Fe}$ in ambient aerosol samples. Photochemically-available Fe ranged from $<4 \mathrm{ng} \mathrm{m}^{-3}$ to $308 \mathrm{ng} \mathrm{m}^{-3}$, and accounted for $2.8 \%$ to $100 \%$ of the total $\mathrm{Fe}$ in aerosol samples collected in California and New York. Calculations based on the results of these experiments predicted that redox reactions of $\mathrm{Fe}$ in cloudwater could be an important in situ source of oxidants ( $\left.\mathrm{OH}, \mathrm{HO}_{2}{ }^{\circ} / \mathrm{O}_{2}^{\circ}\right)$. Chapter 4 presents results of several field studies which measured the redox states of Fe and other transition metals $(\mathrm{Mn}, \mathrm{Cu}$ and $\mathrm{Cr}$ ) in cloudwater. These measurements were then used in thermodynamic models which predicted Fe(III) to be either as Fe(III)-hydroxy species or $\mathrm{Fe}(\mathrm{III})$-oxalate species. However, an un-identified strong chelating ligand with $\mathrm{Fe}(\mathrm{III})$ was also suggested by the thermodynamic model results. Chapter 5 presents results of a field study conducted on the Arabian Sea. Total atmospheric labile-Fe(II) ranged between < $0.09 \mathrm{ng} \mathrm{m}^{-3}$ to $7.5 \mathrm{ng} \mathrm{m}^{-3}$ during the inter-monsoon period, and was consistently below the 
detection limit during the southwest-monsoon period. The labile-Fe(II) measured during the inter-monsoon period was predominantly found in the fine fraction of the aerosol. Principal component analysis revealed a significant source of $\mathrm{Fe}$ and $\mathrm{Mn}$ which was not associated with the main aeolian dust component. 


\section{TABLE OF CONTENTS}

Acknowledgments

Abstract

List of Figures

viii

List of Tables

xii

Chapter 1 Introduction and Overview

Chapter 2 Iron Photochemistry of Aqueous Suspensions of Ambient Aerosol

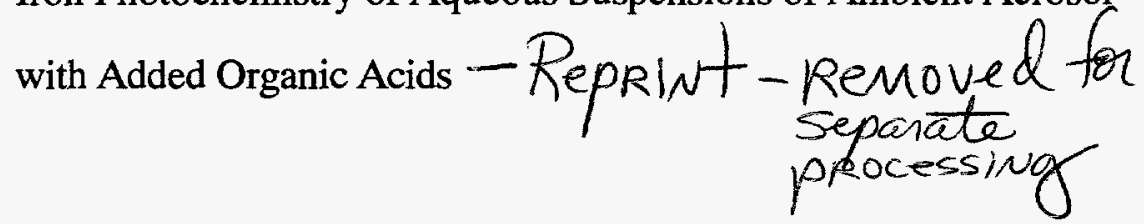

Chapter 3 Determination of Photochemically Available Iron in Ambient Aerosols

Reprint - Removed for separtete processing

Chapter 4 Measurements of Trace Metal (Fe, Cu, Mn, $\mathrm{Cr}$ ) Oxidation States in Fog and Stratus Clouds - Preprint- Removed for
separate processing,

Chapter 5 Chemical Characterization of Ambient Aerosol Collected During the

Southwest-Monsoon and Inter-Monsoon Periods over the Arabian

Sea: Labile-Fe(II) and Other Trace Metals-Prepint -

Chapter 6 Conclusions and Future Work 


\section{LIST OF FIGURES}

\section{Chapter 2:}

Figure 1 Overview of atmospheric iron.

Figure 2 The different measurements conducted for $\mathrm{Fe}$ in ambient aerosol samples.

Figure 3 The different measurements conducted for Fe in cloudwater samples.

\section{Chapter 2:}

Figure $1 \mathrm{H}_{2} \mathrm{O}_{2}$ photoproduction in aqueous solutions of added oxalate and suspended ambient aerosol collected at: $a$, Whiteface Mountain, NY from $9 / 10 / 92$ to $9 / 22 / 92 ; b$, Sequoia National Park, CA from $10 / 5 / 92$ to $10 / 13 / 92$; and $c$, Pasadena, CA from $9 / 1 / 92$ to $9 / 10 / 92$. $\boldsymbol{d}$ is a control experiment without ambient aerosol.

Figure $2 \quad \mathrm{H}_{2} \mathrm{O}_{2}$ photoproduction in aqueous solutions of added oxalate and suspended ambient aerosol collected at: $a$, Sequoia National Park, CA from $10 / 5 / 92$ to $10 / 13 / 92 ; b$ and $c$, Pasadena, CA from $11 / 3 / 92$ to $11 / 9 / 92$.

Figure $3 \mathrm{Fe}(\mathrm{II})_{\mathrm{aq}}$ photoproduction in aqueous solutions of suspended ambient aerosol collected at: $\boldsymbol{a}$, Pasadena, CA from $9 / 1 / 92$ to $9 / 10 / 92$ with no added electron donor; $\boldsymbol{b}$, Pasadena, CA from 9/1/92 to 9/10/92 with 
added formate; $c$, Pasadena, CA from 9/1/92 with added acetate; $\boldsymbol{e}$, Sequoia National Park, CA from 10/5/92 to 10/13/92 with added acetate; and $f$, Pasadena, CA from $11 / 3 / 92$ to $11 / 9 / 92$ with added formate.

\section{Chapter 3:}

Figure 1 Ambient aerosol collection sites: Whiteface Mountain, NY (WMNY); Yosemite National Park, CA (YNPCA); San Nicholas Island, CA (SNICA); Pasadena, CA (PCA).

Figure 2 Reactor vessel used in photochemically-available Fe experiments

Figure $3 \mathrm{Fe}(\mathrm{II})_{\text {aq }}$ production curve in a typical photochemically-available $\mathrm{Fe}$ experiment. The ambient aerosol sample used for this experiment was collected at Yosemite National Park, CA from July 29 to August 9, 1993.

Figure 4 Effect of varying formate concentration on $\mathrm{Fe}(\mathrm{II})_{\mathrm{aq}}$ production rate

Figure 5 Satellite image of the smoke plume from the 1993 Malibu, California fires.

\section{Chapter 4:}

Figure 1 Speciation calculations for $\mathrm{Fe}(\mathrm{III}), \mathrm{Cu}$ (II) and oxalate.

Figure 2 Example of kinetic model results for $\mathrm{Fe}, \mathrm{Cu}$, and $\mathrm{Mn}$. 


\section{Chapter 5:}

Figure 1 Five day air-mass back trajectories for four different elevations (based on pressure) above sea level for: a) May 13, 1996 18:00 UTC, b) May 31, 1996 18:00 UTC, c) July 23, 1996 18:00 UTC and d) August 5, 1996 18:00 UTC.

Figure 2 Log plots of first-row transition metals atmospheric concentrations versus latitude. $O$ symbols represent data collected during M32/3 (inter-monsoon) and $\square$ symbols represent data collected during M32/5 (south-west monsoon).

Figure 3 Log plots of $\mathrm{Mg}_{\text {total, }}, \mathrm{Al}_{\text {total }}, \mathrm{Ti}_{\text {total }}, \mathrm{Ni}_{\text {total }}, \mathrm{Zn}_{\text {total }}$ and $\mathrm{Ba}_{\text {total }}$ versus Latitude. O symbols represent data collected during M32/3 (intermonsoon) and $\square$ symbols represent data collected during M32/5 (south-west monsoon).

Figure 4 Plots of the ratios of $\mathrm{Fe}(\mathrm{II})_{\text {labile }}$ in the "fine" fraction to total Fe(II) $)_{\text {labile }}$ versus Latitude for two labile fractions of $\mathrm{Fe}$ (II) (i.e. Fe(II) $)_{\text {aqueous, labile }}$ and $\left.\mathrm{Fe}(\mathrm{II})_{\text {total, labile }}\right)$.

Figure $5 \mathrm{Log}$ plots of $\mathrm{Na}^{+}{ }_{\text {total }}, \mathrm{K}_{\text {total, }}^{+} \mathrm{Mg}_{\text {total, }}^{2+} \mathrm{Ca}^{2+}{ }_{\text {total }}$, and $\mathrm{NH}_{4}^{+}{ }_{\text {total }}$ versus Latitude. O symbols represent data collected during M32/3 (inter-monsoon) and $\square$ symbols represent data collected during M32/5 (south-west monsoon).

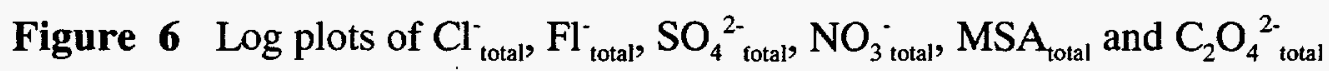
versus Latitude. $O$ symbols represent data collected during M32/3 
(inter-monsoon) and $\square$ symbols represent data collected during M32/5 (south-west monsoon).

Figure 7 Factor score plots for the first 4 principal components shown in Table 7. 


\section{LIST OF TABLES}

\section{Chapter 2:}

Table 1 Collection site, site elevation, collection period, total suspended particulate matter (TSP) and metal concentrations ( $\mathrm{Fe}, \mathrm{Mn}, \mathrm{Cu}, \mathrm{Cr}$ ) for the ambient aerosol collections.

Table 2 Initial $\mathrm{H}_{2} \mathrm{O}_{2}$ production rates for experiments shown in Figure 1 and Figure 2.

\section{Chapter 3:}

Table 1 Summary of ambient aerosol collection locations, collection times, total supended particulate and meteorological conditions.

Table 2 Atmospheric concentrations of total $\mathrm{Fe}\left(\mathrm{Fe}_{\text {total }}\right)$, soluble ferrous $\mathrm{Fe}$ $\left(\mathrm{Fe}(\mathrm{II})_{\text {soluble }}\right)$ and total photochemically-available $\mathrm{Fe}\left(\mathrm{Fe}_{\mathrm{PA}, \text { total }}\right)$. Also the pseudo first-order rate constant $\left(\mathrm{k}^{\prime}\right)$ for the photoreduction of $\mathrm{Fe}(\mathrm{III})_{\mathrm{PA}}$ to $\mathrm{Fe}(\mathrm{II})_{\mathrm{aq}}$ and the initial production rate of $\mathrm{Fe}(\mathrm{II})_{\mathrm{aq}}$.

Table 3 Thermodynamic calculation for $\mathrm{Fe}(\mathrm{II})$ and $\mathrm{Fe}(\mathrm{III})$ speciation.

Table 4 Rate constants for the Fe(II) $)_{\text {aq }}$ oxidation and $\mathrm{Fe}(\mathrm{III})_{\mathrm{aq}}$ reduction reactions, and the calculated $\mathrm{Fe}$ oxidation and reduction rates using the information in Table 3 and assuming $\left[\mathrm{H}_{2} \mathrm{O}_{2}\right]=1 \times 10^{6} \mathrm{M}$. 


\section{Chapter 4:}

Table 1 Cloudwater and fogwater sample collection information.

Table 2 Total elemental concentrations in the cloudwater and fogwater samples. 132

Table 3 Ranges of total metal concentrations and average concentrations for cloudwater and fogwater samples collected in this study and previous studies.

Table 4 Percentage of each element associated with the aqueous phase.

Table 5 Trace metal oxidation states in cloudwater and fogwater samples.

Table 6 S(IV), peroxides, HCHO and anion concentrations in the cloudwater and fogwater samples

Table 7 Enrichment factors (EF) for $\mathrm{Fe}, \mathrm{Cu}, \mathrm{Mn}$ and $\mathrm{Cr}$.

Table 8 Factor analysis statistics for Whiteface Mountain cloudwater samples. 141

Table 9 Principal components (Pcs) after factor analysis of Whiteface Mountain cloudwater samples.

Table 10 Thermodynamic tableau for the speciation calculation in the kinetic model.

Table 11 Reactions and rate constants for kinetic model.

Table 12 Results of kinetic model.

\section{Chapter 5:}

Table 1 Sequential extraction procedure for measuring labile fractions of ferrous iron (Fe(II)) collected on the coarse and fine HVDVI filters. 
Table 2 Strong acid digestion method for HVDVI filters.

Table 3 Aerosol sample collection times and positions.

Table 4 Enrichment factors using the total concentrations of each element (i.e., fine + coarse).

Table 5 Labile $\mathrm{Fe}(\mathrm{II})$ concentrations in the fine and coarse aerosol fractions for M32/3 (inter-monsoon period).

Table 6 Factor analysis statistics for the inter-monsoon and southwestmonsoon data.

Table 7 Prinicpal components (PCs) after factor analysis of inter-monsoon and southwest-monsoon aerosol samples.

Table A1 Total metal concentrations for coarse and fine aerosol fractions.

Table A2 Factor analysis statistics for inter-monsoon data with $\mathrm{Pb}$ and $\mathrm{V}$ measurements.

Table A3 Principal compenents (PCs) after factor analysis of inter-monsoon aerosol samples with $\mathrm{V}$ and $\mathrm{Pb}$ measurements. 


\section{Chapter 1:}

\section{Introduction and Overview}




\section{PREFACE}

This thesis, "Chemical Characterization of Iron in Atmospheric Cloudwater and Aerosols, " consists of four papers. I was first author on all four of these papers. The first paper (Chapter 2) was published in Geochimica et Cosmochimica Acta, the second paper (Chapter 3) was published in The Journal of Geophysical Research, the third paper (Chapter 4) is ready for submission to The Journal of Air and Waste Management, and the fourth paper (Chapter 5) is ready for submission to The Journal of Geophysical Research. Much of this thesis centers around the analysis of aerosol and cloudwater samples collected over the continental United States and the Arabian Sea. I was involved in every component of this research. These components included: 1) aerosol collector design and construction, 2) field preparation, 3) coordination of field studies with other scientists, ship masters, etc., 4) sample collection, 5) sample analysis, 6) thermodynamic and kinetic modeling, 7) statistical analysis, and 8) manuscript writing. Due to the location and duration of the numerous field studies included in this thesis, other people also helped significantly in the collection and chemical analysis of samples. These people included: Anne M. Johansen, Simo O. Pehkonen and Samuel M. Webb. While working on this thesis I also contributed to several other papers and projects related to this thesis, but not included. I was secondauthor on two papers which involved laboratory studies which were relevant to the atmospheric chemistry of Fe. These papers were titled: "Photoreduction of iron oxyhydroxides and photooxidation of halogenated acetic acids: Implications for tropospheric chemistry" [Pehkonen et al., 1995], and "Photoreduction of iron oxyhydroxides in the presence of important atmospheric organic compounds" [Pehkonen et al., 1993]. Both of these papers were published in Environmental Science and Technology. 


\section{INTRODUCTION}

Cloudwater and aerosol chemistry is a poorly understood component of atmospheric chemistry compared to gas-phase atmospheric chemistry. Recent discoveries of sulfur oxidation in clouds ("acid rain") and the role of polar stratospheric clouds (PSCs) in stratospheric ozone chemistry have revealed the importance of cloudwater and aerosol chemistry in the troposphere and stratosphere. Atmospheric Fe is thought to play an important role in cloudwater chemistry (including sulfur oxidation, organic acid production and destruction, and oxidant production and destruction), and is also an important source of $\mathrm{Fe}$ to certain regions of the worlds oceans where $\mathrm{Fe}$ is a rate-limiting nutrient for primary productivity. This thesis focuses on the understanding the chemistry and abundance of Fe in cloudwater and aerosol in the troposphere, through observations of Fe speciation in the cloudwater and aerosol samples collected over the continental United States and the Arabian Sea.

\section{Background}

In order to understand the chemistry occurring in clouds and aerosols, the detailed chemical speciation of transition metals (e.g., $\mathrm{Fe}, \mathrm{Mn}, \mathrm{Cu}$, and $\mathrm{Cr}$ ) must be understood. A knowledge of the transition metal chemical species (for all oxidation states) as a function of variables such as $\mathrm{pH}$, organic ligands, and inorganic ligands is critical to the assessment of atmospheric reaction pathways involving $\mathrm{S}(\mathrm{IV}), \mathrm{O}_{2}, \mathrm{RHCO}, \mathrm{NO}_{x}, \mathrm{ROOH}$ and $\mathrm{H}_{2} \mathrm{O}_{2}$ in heterogeneous phases. In addition, a knowledge of the detailed chemical speciation of $\mathrm{Fe}$ is also important to the assessment of the ability of marine biota to utilize atmosphericallyderived trace elements as micronutrients.

Iron ( $\mathrm{Fe}$ ) is the fourth most abundant element in the earth's crust and the most abundant first-row transition element. Because of it's abundance in the earth's crust, $\mathrm{Fe}$ is 
also the most abundant first-row transition element in atmospheric aerosols since, on a global scale, aeolian dust is a major source of refractory elements to the atmosphere. The next three abundant first-row transition elements in the atmosphere are $\mathrm{Mn}, \mathrm{Cu}$ and $\mathrm{Cr}$. Several studies have investigated the particle size distribution and source identification of these transition metals in the atmosphere [Galloway et al., 1982; Lantzy and Mackenzie, 1979; Nriagu, 1989; Nriagu and Davidson, 1986; Puxbaum, 1991]. But only a few studies have looked at the speciation or reactivity of trace metals in the fogwater or cloudwater [Behra and Sigg, 1990; Erel et al., 1993; Kotronarou and Sigg, 1993; Xue et al., 1991] or in ambient aerosol [Kopcewicz and Kopcewicz, 1991; Kopcewicz and Kopcewicz, 1992; Siefert et al., 1994; Spokes et al., 1994; Zhu et al., 1993; Zhuang et al., 1992].

Iron is predominantly found as either ferric iron ( $\mathrm{Fe}(\mathrm{III})$ ), or ferrous iron ( $\mathrm{Fe}(\mathrm{II}))$ in the earth's crust, lakes and oceans. $\mathrm{Mn}, \mathrm{Cu}$ and $\mathrm{Cr}$ can also be found in several oxidation states in natural waters: 1) $\mathrm{Mn}$ as $\mathrm{Mn}(\mathrm{II}), \mathrm{Mn}(\mathrm{III})$ and $\mathrm{Mn}(\mathrm{IV}), 2) \mathrm{Cu}$ as $\mathrm{Cu}(\mathrm{I})$ and $\mathrm{Cu}(\mathrm{II})$, and 3) $\mathrm{Cr}$ as $\mathrm{Cr}(\mathrm{III})$ and $\mathrm{Cr}(\mathrm{VI})$. These metals are known to participate in a variety of redox reactions in natural waters involving S(IV), organic compounds, oxidants and metal ions [Conklin and Hoffmann, 1988; Faust and Hoffmann, 1986; Graedel et al., 1986; Weschler et al., 1986; Wiersma and Davidson, 1986]. Fe and Mn are also found as particulate oxides and hydrous oxides in natural waters, which can also participate in a variety of redox reactions on the surface of these particles which are similar to those of dissolved Fe and Mn [Faust and Hoffmann, 1986; Kieber and Helz, 1992; Regazzoni and Blesa, 1991; Siffert and Sulzberger, 1991; Stone, 1986].

Figure 1 shows an overview of $\mathrm{Fe}$ in the atmosphere. Sources of $\mathrm{Fe}$ and other transition elements to the atmosphere include: aeolian dust, volcanic activity and anthropogenic sources [Nriagu, 1989; Nriagu and Davidson, 1986; Puxbaum, 1991]. Meteoritic $\mathrm{Fe}$ is also a detectable source of $\mathrm{Fe}$ to the atmosphere [Kopcewicz and Kopcewicz, 1992]. Once in the atmosphere Fe can be cycled between "dry" aerosol 
particles (hereafter referred to as aerosol particles) and cloudwater droplets. "Dry" refers to atmospheric conditions where the relative humidity is not high enough (i.e., supersaturation conditions) for the aerosol particles to grow to cloud-size drops. These "dry" aerosol particles can be incorporated into cloud droplets by either the aerosol particle serving as a nucleus for a cloud drop, or an interstitial aerosol particle impacting on preexisting cloud drop. Overall, aerosol particles undergo an estimated of 10 nucleation/evaporation cycles before they are removed from the atmosphere by wet or dry deposition [Junge, 1964]. Once in a cloud droplet, Fe can be involved in S(IV) oxidation, organic acid production/destruction, and oxidant (e.g., ${ }^{\circ} \mathrm{OH}, \mathrm{HO}_{2}$ ) production/destruction [Graedel et al., 1986; Faust, 1994 ; Jacob et al., 1989]. This chemistry can also potentially change the speciation or mineral form of $\mathrm{Fe}$ present in the atmosphere, effectively "weathering" the $\mathrm{Fe}$ as it is advected. Finally, the $\mathrm{Fe}$ is removed from the atmosphere through either wet or dry deposition. This deposition is critical to certain regions of the oceans where $\mathrm{Fe}$ is a rate-limiting nutrient to phytoplankton growth and therefore determines the primary productivity of these regions of the oceans [Ditullio et al., 1993; Kolber et al., 1994; Martin et al., 1994; Martin and Gordon, 1988; Price et al., 1994]. The metal speciation is critical to the ability of the marine biota to utilize atmospherically-derived trace elements as micronutrients [Hudson and Morel, 1990; Hudson and Morel, 1993; Morel et al., 1991; Wells et al., 1994; Wells et al., 1995]. The primary source of Fe to these regions of the oceans is through atmospheric deposition .

\section{Thesis Work}

The goal of this thesis was to characterize atmospheric $\mathrm{Fe}$, along with various other species relevant to the chemistry of $\mathrm{Fe}$, in cloudwater and aerosol to help understand the role of $\mathrm{Fe}$ in heterogeneous atmospheric chemistry, and also its role as a nutrient source to surface ocean waters. This goal was achieved by the development and application of several collection and analytical methods. These methods were used in a multitude of field 
studies to investigate Fe speciation in aerosol and cloudwater. Figure 2 outlines the different measurements conducted for Fe in ambient aerosol samples. Figre 3 outlines the different measurements conducted for Fe in cloudwater samples.

The second chapter discusses experiments using atmospheric aerosol samples collected from Whiteface Mtn. (NY), Pasadena (CA), and Sequoia National Park (CA). The aerosol samples were suspended in aqueous solutions ("simulated cloudwater"), followed by addition of various organic acids (oxalic, formic and acetic acids), which are commonly observed in cloudwater. The solution was then irradiated with ultraviolet light (similar intensity to ambient sunlight) and various species were measured (i.e., $\mathrm{H}_{2} \mathrm{O}_{2}$, $\mathrm{Fe}(\mathrm{II})_{\mathrm{aq}}$ and $\left.\mathrm{pH}\right)$. These experiments found $\mathrm{Fe}$ to be a critical component for the production of $\mathrm{H}_{2} \mathrm{O}_{2}$ in the simulated cloudwater experiments.

The third chapter discusses the development and application of a novel photochemical extraction method for the determination of photochemically-available $\mathrm{Fe}$. This method was used to characterize Fe in aerosol samples collected from Whiteface Mtn. (NY), Pasadena (CA), San Nicholas Island (CA) and Yosemite National Park (CA). Several aerosol samples were collected during biomass burning episodes. Photochemically-available Fe ranged from $<4 \mathrm{ng} \mathrm{m}^{-3}$ to $308 \mathrm{ng} \mathrm{m}^{-3}$, and accounted for $2.8 \%$ to $100 \%$ of the total $\mathrm{Fe}$ in the sample. Calculations based on the results of these experiments predicts that redox reactions of $\mathrm{Fe}$ in cloudwater could be an important in situ source of oxidants ( $\left.\mathrm{OH}, \mathrm{HO}_{2}^{\circ} / \mathrm{O}_{2}^{\circ}\right)$.

The fourth chapter discusses results of several field studies which measured the redox states of $\mathrm{Fe}$ and other transition metals $(\mathrm{Mn}, \mathrm{Cu}$ and $\mathrm{Cr})$ in cloudwater. Other measurements, relevant to the speciation and redox chemistry of these metals, included: $\mathrm{pH}$, total elemental concentrations, organic anions, inorganic anions, cations, peroxides, and formaldehyde. Several cloud events were sampled at Whiteface Mtn (NY), San Pedro Hill (CA) and Bakersfield (CA). The results of the measurements were then used in thermodynamic models to calculate the speciation of the metals in the cloudwater samples. 
$\mathrm{Fe}$ (III) was found to occur either as Fe(III)-hydroxy species or Fe(III)-oxalate species. However, an un-identified strong chelating ligand with Fe(III) was also suggested by the data. A kinetic model was also used to investigate the metal redox chemistry.

The fifth chapter discusses results of a field study conducted aboard the research vessel Meteor on the Arabian Sea. Aerosol samples were collected and immediately analyzed for labile-Fe(II) fractions (along with other important species) during two separate cruises in 1995. The first cruise occurred during the inter-monsoon period and the second occurred during the southwest-monsoon. A high volume dichotomous virtual impactor (HVDVI) was used to collect aerosol in the fine and coarse fractions. Total atmospheric labile-Fe(II) ranged between $<0.09 \mathrm{ng} \mathrm{m}^{-3}$ and $7.5 \mathrm{ng} \mathrm{m}^{-3}$ during the inter-monsoon period, and was consistently below the detection limit during the southwest-monsoon period. The labile-Fe(II) measured during the inter-monsoon period was found predominantly in the fine fraction of the aerosol. Principal component analysis revealed a significant source of $\mathrm{Fe}$ and $\mathrm{Mn}$ which was not associated with the main aeolian dust component.

Overall, this thesis has provided further insight into cloudwater and aerosol chemistry in the atmosphere. However, more sensitive analytical methods, better collection techniques, and laboratory experiments will certainly bring new discoveries regarding these complicated dynamic systems. 


\section{FIGURE CAPTIONS}

FIGURE 1 Overview of atmospheric iron.

FIGURE 2 The different measurements conducted for $\mathrm{Fe}$ in ambient aerosol samples.

FIGURE 3 The different measurements conducted for $\mathrm{Fe}$ in cloudwater samples. 


\section{REFERENCES}

Behra, P., and L. Sigg, Evidence for redox cycling of iron in atmospheric water droplets, Nature, 344 (6265), 419-421, 1990.

Conklin, M.H., and M.R. Hoffmann, Metal ion-sulfur(IV) chemistry. 2. Kinetic studies of the redox chemistry of copper(II)-sulfur(IV) complexes, Environ. Sci. Technol., 22, $891-898,1988$.

Ditullio, G.R., D.A. Hutchins, and K.W. Bruland, Interaction of iron and major nutrients controls phytoplankton growth and species composition in the tropical North Pacific Ocean, Limnol. \& Ocean., 38 (3), 495-508, 1993.

Erel, Y., S.O. Pehkonen, and M.R. Hoffmann, Redox chemistry of iron in fog and stratus clouds, J. Geophys. Res. A., 98 (D10), 18423-18434, 1993.

Faust, B.C., Photochemistry of clouds, fogs and aerosols, Environ. Sci. Technol., 28 (5), 217A-222A, 1994.

Faust, B.C., and M.R. Hoffmann, Photoinduced reductive dissolution of alpha-Fe2O3 by bisulfite, Environ. Sci. Technol., 20, 943-948, 1986.

Galloway, J.N., J.D. Thornton, S.A. Norton, H.L. Volchok, and R.A.N. Mclean, Tracemetals in atmospheric deposition - A review and assessment, Atmos. Environ., 16, 1677 1700, 1982. 
Graedel, T.E., M.L. Mandich, and C.J. Weschler, Kinetic model studies of atmospheric droplet chemistry, 2. Homogenous transition metal chemistry in raindrops, J. Geophys. Res., 91, 5205-5221, 1986.

Hudson, R.J.M., and F.M.M. Morel, Iron transport in marine phytoplankton: Kinetics of cellular and medium coordination reactions, Limnol. Ocean., 35 (5), 1002-1020, 1990.

Hudson, R.J.M., and F.M.M. Morel, Trace-metal transport by marine microorganisms: Implications of metal coordination kinetics, Deep Sea Res., 40, 129-150, 1993.

Jacob, D.J., E.W. Gottlieb, and M.J. Prather, Chemistry of the polluted boundary layer, J. Geophys. Res., 94, 12975-13002, 1989.

Junge, C.E., The modification of aerosol size distribution in the atmosphere, US Army, 1964.

Kieber, R.J., and G.R. Helz, Indirect photoreduction of aqueous chromium(VI), Environ. Sci. Technol., 26, 307-312, 1992.

Kolber, Z.S., R.T. Barber, K.H. Coale, S.E. Fitzwater, R.M. Greene, K.S. Johnson, S. Lindley, and P.G. Falkowski, Iron limitation of phytoplankton photosynthesis in the equatorial Pacific Ocean, Nature, 371 (6493), 145-149, 1994.

Kopcewicz, B., and M. Kopcewicz, Mossbauer study of iron-containing atmospheric aerosols, Struct. Chem., 2 (3-4), 303-312, 1991. 
Kopcewicz, B., and M. Kopcewicz, Seasonal variations of iron concentration in atmospheric aerosols, Hyperfine Interactions, 71 (1-4), 1457-1460, 1992.

Kotronarou, A., and L. Sigg, SO2 Oxidation in atmospheric water: role of $\mathrm{Fe}(\mathrm{II})$ and effect of ligands, Environ. Sci. \& Technol., 27 (13), 2725-2735, 1993.

Lantzy, R.J., and F.T. Mackenzie, Atmospheric trace metals: Global cycles and assessment of Man's impact, Geochim. et Cosmochim. Acta, 43, 511-523, 1979.

Martin, J.H., K.H. Coale, K.S. Johnson, S.E. Fitzwater, R.M. Gordon, S.J. Tanner, C.N. Hunter, V.A. Elrod, J.L. Nowicki, and e. al., Testing the iron hypothesis in ecosystems of the equatorial Pacific Ocean, Nature, 371 (6493), 123-129, 1994.

Martin, J.H., and R.M. Gordon, Northeast Pacific iron distributions in relation to phytoplankton productivity, Deep Sea Res. A., 35 (2), 177-196, 1988.

Morel, F.M.M., R.J.M. Hudson, and N.M. Price, Limitation of productivity by tracemetals in the sea, Limnol. Oceanogr., 36 (8), 1742-17455, 1991.

Nriagu, J.O., A global assessment of natural sources of atmospheric trace metals, Nature, $338,47-49,1989$.

Nriagu, J.O., and C.I. Davidson, Toxic metals in the atmosphere, in Advances in environmental science and technology, Wiley, New York, 1986. 
Pehkonen, S.O., R.L. Siefert, Y. Erel, S. Webb, and M.R. Hoffmann, Photoreduction of iron oxyhydroxides in the presence of important atmospheric organic compounds, Environ. Sci. Technol., 27 (10), 2056-2062, 1993.

Pehkonen, S.O., R.L. Siefert, and M.R. Hoffmann, Photoreduction of iron oxyhydroxides and the photooxidation of halogenated acetic acids, Environ. Sci. Technol., $29,1215-1222,1995$.

Price, N.M., B.A. Ahner, and F.M.M. Morel, The equatorial Pacific Ocean - grazer controlled phytoplankton populations in an iron limited ecosystem, Limnol. \& Ocean., 39 (3), 520-534, 1994.

Puxbaum, H., Metal compounds in the atmosphere, in Metals and their compounds in the environment, edited by E. Merian, pp. 257-286, VCH Publishers, 1991.

Regazzoni, A.E., and M.A. Blesa, Reactivity of surface Fe(III)-thiocyanate complexes characterized by the dissolution of hematite in acidic thiocyanate solutions, Langmuir, 7, 473-478, 1991.

Siefert, R.L., S.O. Pehkonen, Y. Erel, and M.R. Hoffmann, Iron photochemistry of aqueous suspensions of ambient aerosol with added organic acids, Geochim. et Cosmochim. Acta, 58 (15), 3271-3279, 1994.

Siffert, C., and B. Sulzberger, Light-induced dissolution of hematite in the presence of oxalate: a case study, Langmuir, 7, 1627-1634, 1991. 
Spokes, L.J., T.D. Jickells, and B. Lim, Solubilisation of aerosol trace metals by cloud processing: A laboratory study, Geochim. et Cosmochim. Acta, 58 (15), 3281-3287, 1994.

Stone, A.T., Adsorption of organic reductants and subsequent electron transfer on metal oxide surfaces, in Geochemical Processes at Mineral Surfaces, edited by J.A. Davis, and K.F. Hayes, American Chem. Soc., 1986.

Wells, M.L., N.M. Price, and K.W. Bruland, Iron limitation and the cyanobacterium synechococcus in equatorial pacific waters, Limnol. Ocean., 39 (6), 1481-1486, 1994.

Wells, M.L., N.M. Price, and K.W. Bruland, Iron chemistry in seawater and its relationship to phytoplankton: a workshop report, Marine Chem., 48, 157-182, 1995.

Weschler, C.J., M.L. Mandich, and T.E. Graedel, Speciation, photosensitivity, and reactions of transition metal ions in atmospheric droplets, J. Geophys. Res., 91, 5189$5204,1986$.

Wiersma, G.B., and C.I. Davidson, Trace metals in the atmosphere of remote areas, in Toxic trace metals in the atmosphere, edited by J.O. Nriagu, and C.I. Davidson, pp. 201266, Wiley, New York, 1986.

Xue, H.B., M.D.S. Goncalves, M. Reutlinger, L. Sigg, and W. Stumm, Copper(I) in fogwater: determination and interactions with sulfite, Environ. Sci. \& Technol., 25 (10), 1716-1722, 1991. 
Zhu, X.R., J.M. Prospero, D.L. Savoie, F.J. Millero, R.G. Zika, and E.S. Saltzman, Photoreduction of iron(III) in marine mineral aerosol solutions, J. Geophys. Res. A., 98 (ND5), 9039-9046, 1993.

Zhuang, G., Z. Yi, R.A. Duce, and P.R. Brown, Link between iron and sulfur cycles suggested by detection of Fe(II) in remote marine aerosols, Nature, 355 (6360), 537-539, 1992. 


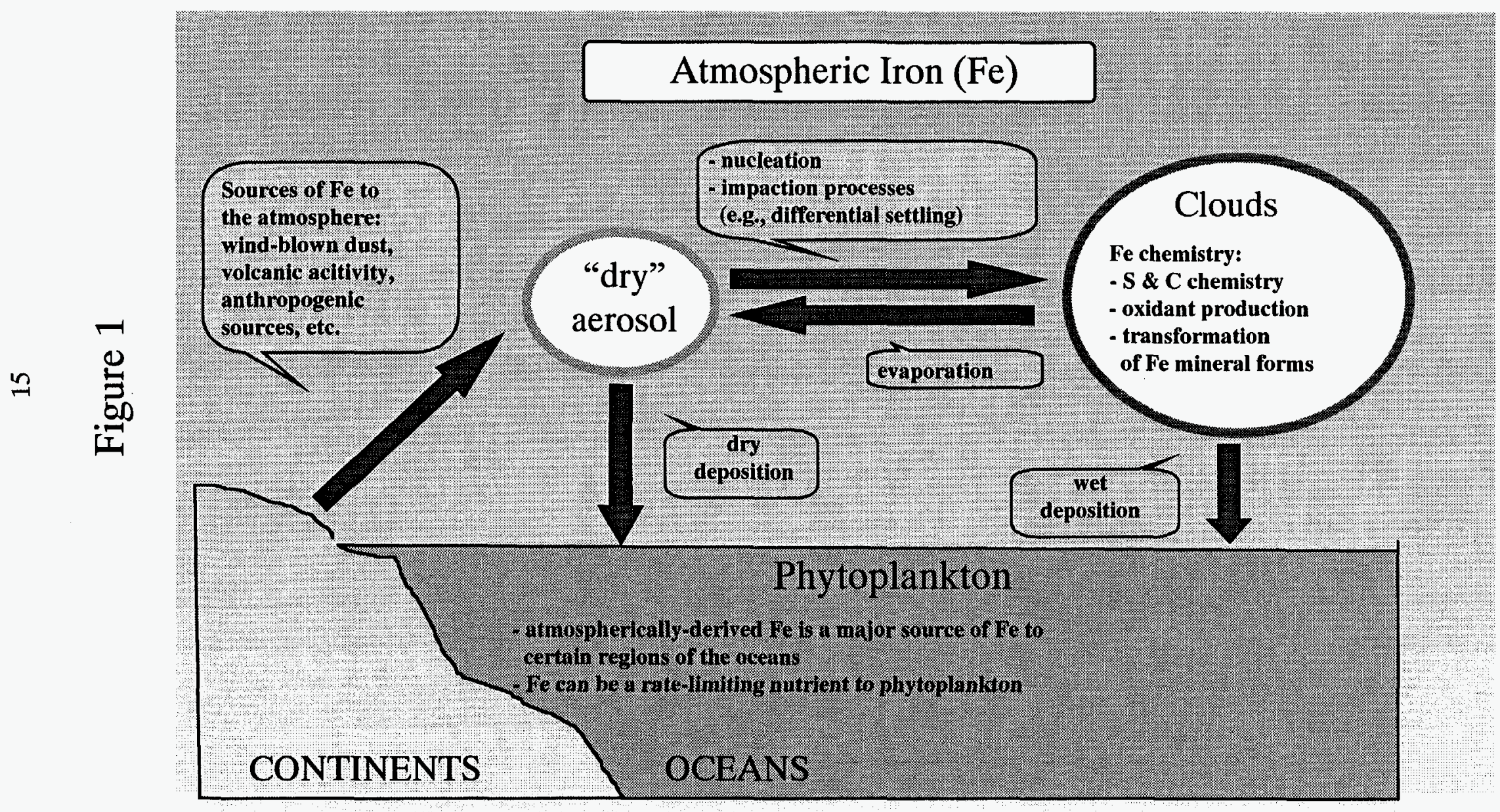


Figure 2

\section{Fe ANALYSIS IN AEROSOL SAMPLES}

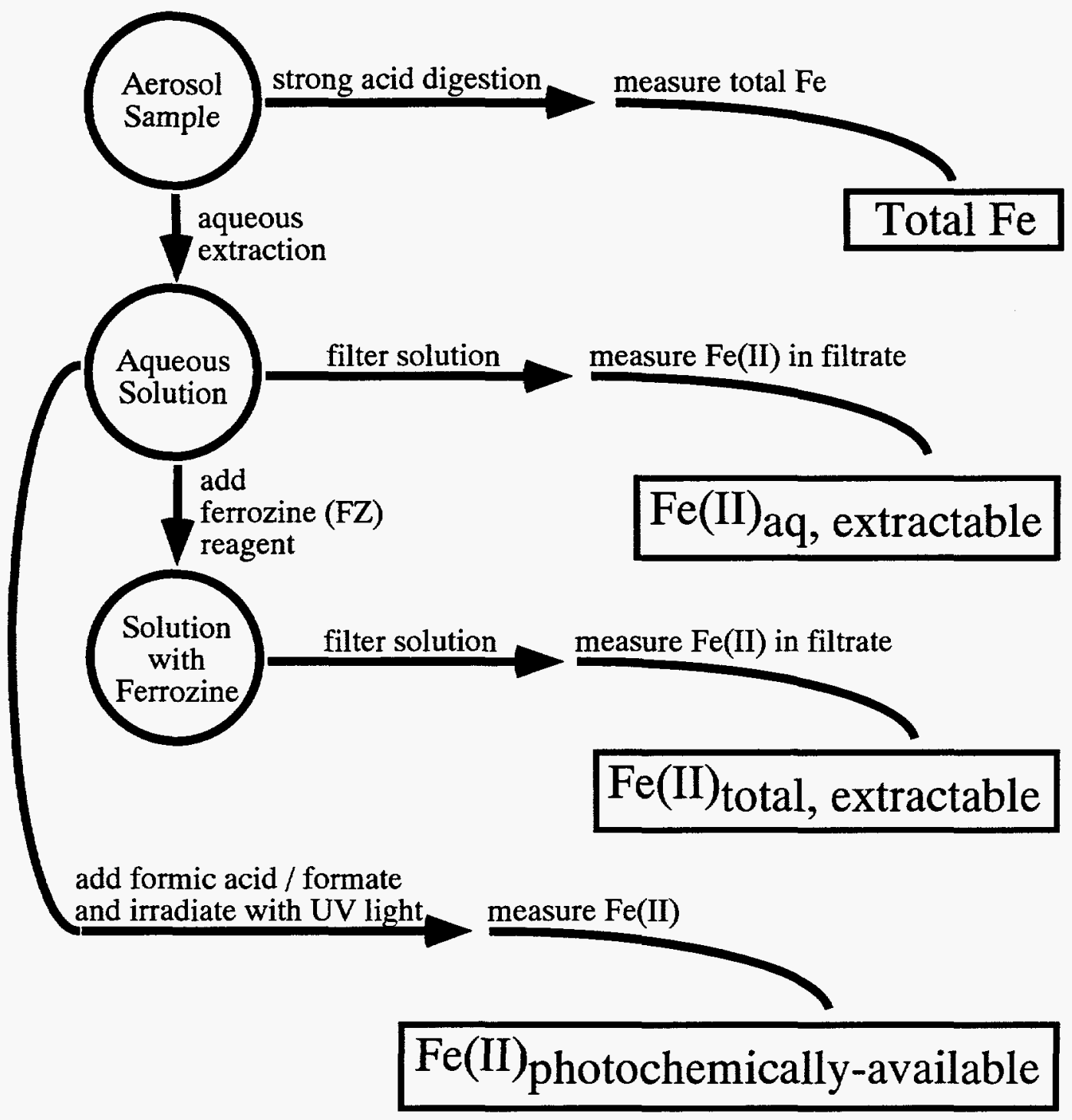


Figure 3

\section{Fe ANALYSIS IN CLOUDWATER SAMPLES}

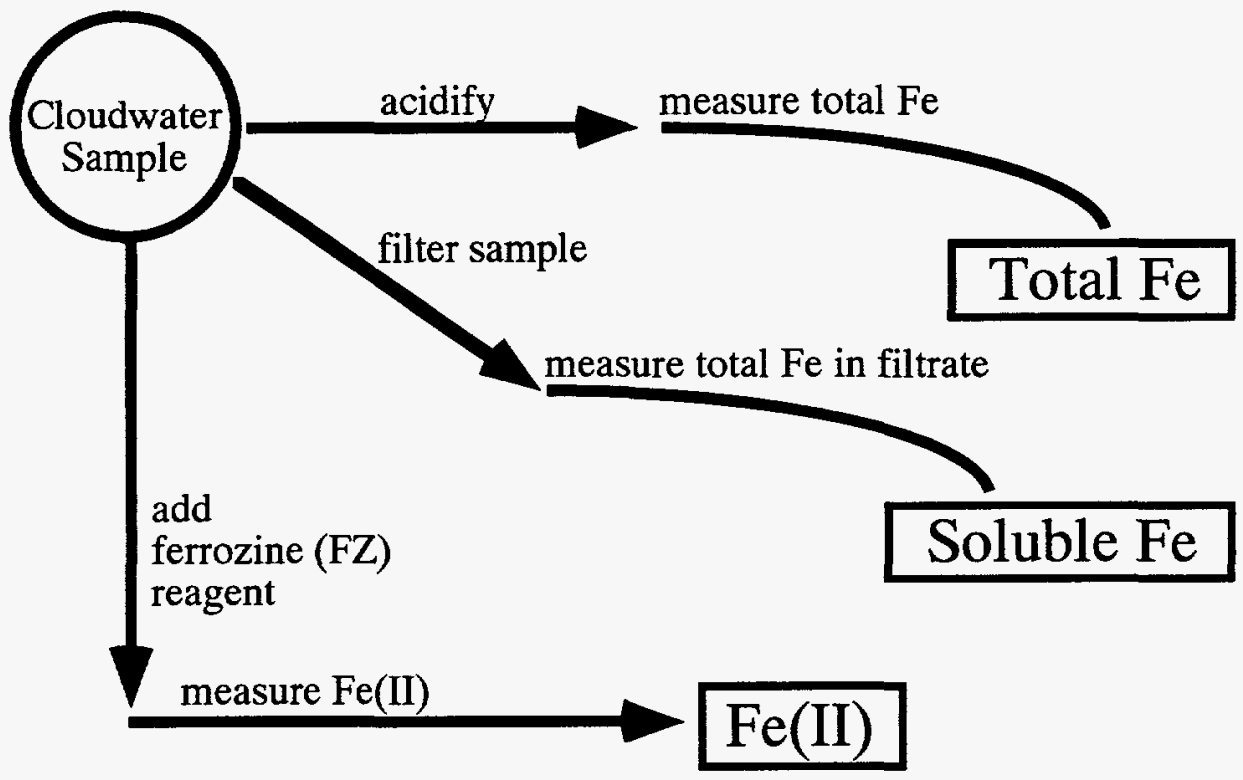




\section{Chapter 6:}

Conclusions and Future Work 


\section{CONCLUSIONS}

Experiments, using ambient aerosol samples suspended in aqueous solutions to simulate cloudwater chemistry, along with the measurement of different chemical species of $\mathrm{Fe}$ in aerosol and cloudwater samples, were used to assess the role of $\mathrm{Fe}$ in cloudwater chemistry. These measurements included several labile fractions of $\mathrm{Fe}(\mathrm{II})$ and photochemically-available Fe. Many other species, relevant to the chemistry of Fe, were also measured. The aerosol and cloudwater samples were collected from a variety of locations to understand spatial variability. The sampling sites included: Pasadena (CA), San Nicholas Island (CA), Sequoia National Park (CA), Yosemite National Park (CA), Whiteface Mountain (NY), and the Arabian Sea. Thermodynamic and kinetic models, along with statistical methods were used to interpret the field observations.

Experiments to simulate cloudwater conditions were carried out by suspending ambient aerosol samples in an aqueous solution and then irradiating the solution with ultraviolet light. A total of four different ambient aerosol samples were used in the simulated cloudwater experiments; they were collected from Whiteface Mountain, NY (1), Pasadena, CA (2) and Sequoia National Park, CA (1). In all cases, the production rates for $\mathrm{Fe}(\mathrm{II})_{\mathrm{aq}}$ and $\mathrm{H}_{2} \mathrm{O}_{2}$ in the light were greater than production rates in non-irradiated control experiments. The simulated cloudwater experiments (with 4 different aerosol samples) showed similar behavior to previous experiments carried out with synthetic Fe-oxyhydroxy polymorphs in the presence of oxalate, formate or acetate. The Fe present in the ambient aerosol appears to be a critical component for the production of $\mathrm{H}_{2} \mathrm{O}_{2}$ in the simulated cloudwater experiments.

A novel photochemical extraction procedure was developed and used to determine the concentration of photochemically-available $\mathrm{Fe}$ in ambient aerosol samples. Ambient aerosol samples, collected at Whiteface Mountain (NY), Pasadena (CA) and San Nicholas 
Island (CA), were suspended in an aqueous solution within a photochemical reactor and irradiated. Under these conditions, which were favorable to the photo-chemical weathering of aerosol particles, the relative amount of $\mathrm{Fe}(\mathrm{II})_{\mathrm{aq}}$ to $\mathrm{Fe}_{\text {total }}$ was shown to increase and used to characterize the $\mathrm{Fe}$ in the aerosol samples. Photochemically-available Fe concentrations found ranged from $<4 \mathrm{ng} / \mathrm{m}^{3}$ to $308 \mathrm{ng} / \mathrm{m}^{3}$ and the percentage of photochemicallyavailable $\mathrm{Fe}$ to $\mathrm{Fe}_{\text {total }}$ ranged from $2.8 \%$ to $100 \%$. Aerosol samples were also collected during biomass burning events in Southern California; these samples showed insignificant changes in the photochemically-available Fe (compared to non-biomass burning samples) in conjunction with large increases of $\mathrm{Fe}_{\text {total }}$. Calculations based on these experiments also provides further evidence that redox reactions of $\mathrm{Fe}$ in cloudwater could be an important in situ source of oxidants ( $\left.\mathrm{OH}, \mathrm{HO}_{2}{ }^{\circ} / \mathrm{O}_{2}^{-}\right)$.

Other transition metals also may play an important role in the atmospheric chemistry of Fe. Therefore, the oxidation state of $\mathrm{Fe}$ and three other transition metals $(\mathrm{Mn}, \mathrm{Cu} \& \mathrm{Cr})$ in cloudwater were investigated during several cloud events at Whiteface Mountain (NY), one cloud event at San Pedro Hill (CA) and one fog event at Bakersfield (CA). Other measurements performed, relevant to the redox chemistry of these metals, included $\mathrm{pH}$, total elemental concentrations ( $\mathrm{Fe}, \mathrm{Cu}, \mathrm{Mn}, \mathrm{Cr}, \mathrm{Al}, \mathrm{K}, \mathrm{Ca}, \mathrm{Na}$ and $\mathrm{Mg}$ ), organic anions (formate, acetate, glycolate, oxalate), inorganic anions (chloride, sulfate, nitrate, sulfite), cations (sodium, calcium, magnesium, potassium), peroxides, and formaldehyde. These measurements were then used in thermodynamic speciation models to understand the speciation of ambient fog and cloudwater. From this analysis, two different cases were found for $\mathrm{Fe}(\mathrm{III})_{\text {soluble }}$ speciation. $\mathrm{Fe}(\mathrm{III})$ was found to exist either as $\mathrm{Fe}(\mathrm{OH})_{2}^{+}$or $\mathrm{Fe}(\mathrm{Oxalate})_{2} \cdot$ However, an un-identified strong chelating ligand with $\mathrm{Fe}$ (III) was also suggested by the data. $\mathrm{Cu}(\mathrm{I})$ and $\mathrm{Cu}(\mathrm{II})$ were calculated to be predominantly $\mathrm{Cu}^{+}$and $\mathrm{Cu}^{2+}$ (with less than $10 \%$ as $\mathrm{Cu}$ (II)-oxalate complexes). A chemical kinetic model was also used to investigate the transition metal chemistry. The model results indicate $\mathrm{Fe}(\mathrm{II})$ should be the predominant chemical form of Fe during daylight conditions. This prediction is in 
agreement with the field measurements in which the highest ratios of $\mathrm{Fe}(\mathrm{II}) / \mathrm{Fe}_{\text {total }}$ were found in samples collected during the day. The model results also indicated Fe(III) should be the predominant form of Fe during nighttime conditions, this is also in agreement with the field measurements. In the model, $\mathrm{Cu}$ (II) and $\mathrm{Mn}$ (II) were the predominant oxidation states during daylight and nighttime conditions, with $\mathrm{Cu}(\mathrm{I})$ and $\mathrm{Mn}(\mathrm{III})$ increasing during daylight conditions. $\mathrm{Mn}$ (III) concentrations were never high enough to influence the redox chemistry of $\mathrm{Cr}$. Overall, $\mathrm{Cr}(\mathrm{VI})$ in cloudwater is predicted to be reduced to $\mathrm{Cr}(\mathrm{III})$.

Ambient aerosol samples were also collected during the inter-monsoon and southwest-monsoon periods on the Arabian Sea. A high-volume dichotomous virtual impactor (HVDVI) with an aerodynamic cutoff size of $3 \mu \mathrm{m}$ was used to collect the fine and coarse aerosol fractions for metal analysis. A low volume collector (LVC) was used to collect aerosol samples for anion and cation analysis. The primary purpose of this study was to characterize the chemical composition of the ambient aerosol during the southwestmonsoon and inter-monsoon periods, including the measurement of labile ferrous iron (Fe(II)) in the fine and coarse fractions of ambient aerosol samples. The analysis for labileFe(II) was done immediately after sample collection to minimize any possible Fe redox reactions which might occur during sample storage. Total atmospheric aqueous labile$\mathrm{Fe}$ (II) concentrations during the inter-monsoon period were between $7.48 \mathrm{ng} \mathrm{m}^{-3}$ to < $0.089 \mathrm{ng} \mathrm{m}^{-3}$. The aqueous-labile $\mathrm{Fe}(\mathrm{II})$ was predominantly in the "fine" fraction $(<3.0$ $\mu \mathrm{m}$ ), with the "fine" fraction of aqueous labile Fe(II) accounting for an average of $90 \%$ of the total aqueous labile $\mathrm{Fe}(\mathrm{II})$. In contrast, during the southwest-monsoon period, the atmospheric aqueous labile $\mathrm{Fe}$ (II) concentrations were consistently below the detection limit ( $<0.34 \mathrm{ng} \mathrm{m}^{-3}$ to $<0.089 \mathrm{ng} \mathrm{m}^{-3}$ depending on the volume of air sampled). Factor analysis revealed a significant source of $\mathrm{Fe}$ and $\mathrm{Mn}$ which was not associated with the main aeolian dust component or any typical anthropogenic metals (e.g. $\mathrm{V}, \mathrm{Pb}$ ). This component did not include any loadings of labile-Fe(II). The air mass back trajectories (5 day, threedimensional) showed that air masses sampled during the southwest-monsoon had origins 
over the open Indian Ocean, and air masses sampled during the inter-monsoon had origins from southeast Africa, Saudi Arabian peninsula, and southern Asia.

\section{FUTURE WORK}

This thesis has provided insight into the role of $\mathrm{Fe}$ chemistry in the atmosphere. However, much is still unknown about Fe and other transition metal chemistry in aerosol and cloudwater. The major challenge in this thesis was the difficulty associated with analyzing trace species in aerosol and cloudwater. Current spectrophotometric techniques used in this thesis for the quantification of $\mathrm{Fe}$ (II) and other trace metal oxidation states have serious limitations. These limitations include interferences with other aerosol and cloudwater chemical species, and sensitivity. Great care must be taken to eliminate the interferences or account for them. As for sensitivity, relatively large sample sizes must be collected for both aerosol and cloudwater in order to be in the range of the analytical technique. These large sample sizes ultimately require long sampling times, which are usually longer than the characteristic times associated with the reactions occurring in the aerosol or cloudwater system being sampled. Improved analytical and collection techniques which provide for the near real-time analysis of trace metal speciation in ambient aerosol and cloudwater systems would provide invaluable knowledge. Techniques, such as electro-spray mass spectrometry (ES-MS) show a great deal of promise, however their application to field studies is currently limited by the size and complexity of the instrumentation. And the problems associated with coupling an ES-MS instrument to a cloudwater collector are numerous. 